Artigo

\title{
The Use of Fire Radiative Power to Estimate the Biomass Consumption Coefficient for Temperate Grasslands in the Atlantic Forest Biome
}

\author{
Bibiana Salvador Cabral da Costa $^{1}$, Eliana Lima da Fonseca ${ }^{2}$ \\ ${ }^{1}$ Programa de Pós-Graduação em Sensoriamento Remoto, Centro Estadual de Pesquisas em \\ Sensoriamento Remoto e Meteorologia, Universidade Federal do Rio Grande do Sul, \\ Porto Alegre, RS, Brasil. \\ ${ }^{2}$ Departamento de Geografia, Instituto de Geociências, \\ Universidade Federal do Rio Grande do Sul, Porto Alegre, RS, Brasil.
}

Received in May 15, 2016 - Accepted in December 29, 2016

\begin{abstract}
Every year, many active fire spots are identified in the satellite images of the southern Brazilian grasslands in the Atlantic Forest biome and Pampa biome. Fire Radiative Power (FRP) is a technique that uses remotely sensed data to quantify burned biomass. FRP measures the radiant energy released per time unit by burning vegetation. This study aims to use satellite and field data to estimate the biomass consumption rate and the biomass consumption coefficient for the southern Brazilian grasslands. Three fire points were identified in satellite FRP products. These data were combined with field data, collected through literature review, to calculate the biomass consumption coefficient. The type of vegetation is an important variable in the estimation of the biomass consumption coefficient. The biomass consumption rate was estimated to be $2.237 \mathrm{~kg} \mathrm{~s}^{-1}$ for the southern Brazilian grasslands in Atlantic Forest biome, and the biomass consumption coefficient was estimated to be $0.242 \mathrm{~kg} \mathrm{MJ}^{-1}$.
\end{abstract}

Keywords: remote sensing, rangelands, burnings, wildfire, Campos de Cima da Serra, Pampa.

\section{Uso da Potencia Radiativa do Fogo para Estimar o Coeficiente de Consumo de Biomassa em Gramíneas Temperadas no Bioma Mata Atlântica}

\begin{abstract}
Resumo
Todos os anos muitos focos de incêndio são identificados pelas imagens de satélite sobre a vegetação campestre natural dos biomas Pampa e Mata Atlântica. A Energia Radiativa do Fogo (FRP) é uma técnica para quantificar a biomassa queimada usando dados de sensoriamento remoto. A FRP mede a energia radiante emitida por unidade de tempo pela vegetação queimada. O objetivo deste estudo foi estimar o coeficiente de consumo de biomassa para a vegetação campestre natural do sul do Brasil. Três focos de incêndio foram identificados em produtos de satélite que quantificam a FRP. Esses dados foram utilizados em conjunto com os dados de campo, obtidos por revisão de literatura, para calcular o coeficiente de consumo de biomassa. O tipo de vegetação é uma variável importante para estimar esse coeficiente, assim, para a vegetação campestre natural do bioma Mata Atlântica no sul do Brasil a taxa de consumo de biomassa foi estimada em 2,237 $\mathrm{kg} \mathrm{s}^{-1}$ e o coeficiente de consumo de biomassa foi estimado em 0,242 $\mathrm{kg} \mathrm{MJ}^{-1}$.
\end{abstract}

Palavras-chave: sensoriamento remoto, campo nativo, queimadas, Campos de Cima da Serra, Pampa.

\section{Introduction}

The southern Brazilian grasslands, broadly called Campos, occur in two different biomes, namely the Pampa biome and the Atlantic Forest biome. These grasslands are closely associated with livestock production, as they are the main forage supply for cattle and sheep. However, the livestock do not completely consume the grasslands aboveground biomass produced during the summer season. Hence, to avoid biomass accumulation, farmers undertake common fire control practices at the end of the winter season, between August and September, usually every year

Autor de correspondência: Eliana Lima da Fonseca, eliana.fonseca@ufrgs.br. 
(Heringer and Jacques, 2002; Overbeck et al., 2007; Boldrini, 2009; Fidelis et al., 2012). The satellite images acquired annually for this region show many active fires in both biomes. Nevertheless, only a few studies on wildfires are carried out in the southern Brazilian grasslands with the use of satellite data.

A wildfire is a fire in the countryside that burns strongly and out of control, and it develops through four different stages: ignition, flames, smoldering, and extinction (Whelan, 1995; Freitas et al., 2005). The fire intensity can vary mainly in relation to the moisture content of the combustible material, the wind, air temperature, humidity and slope. The amount of available fuel load is one of the most important variables that affect the behavior and severity of fire (Whelan, 1995). The gases and aerosols emitted into the atmosphere during the combustion process of a burning exert a significant influence on the atmospheric chemistry and on the regional and global planetary ecology (Andreae and Merlet, 2001; Longo et al., 2009). Most of these emissions occur during the flame and smoldering stages (Freitas et al., 2005). The majority of carbon monoxide and dioxide emission and water release happens during the flame stage; in the smoldering stage, most of the trace gases and particulate matter are released (Andreae, 1991).

The burned biomass can be quantified using Eq. (1) (Seiler and Crutzen, 1980), where $B C$ is the biomass consumption amount $(\mathrm{kg}) ; A$ is the burned area measure $\left(\mathrm{m}^{2}\right) ; B$ is the biomass amount inside the burned area $\left(\mathrm{kg} \mathrm{m}^{-2}\right)$; and $\beta$ is the combustion efficiency, or the fraction of fuel that actually burned.

$$
B C=A \times B \times \beta
$$

The amount of gases and particulate matter released into the atmosphere during the combustion process can be estimated by integrating the remotely sensed data with the burned biomass amount and the chemical compounds emission factors (Longo et al., 2009). To quantify the burned biomass using remotely sensed data, the Fire Radiative Power (FRP) technique (Wooster et al., 2005) uses satellite data to measure the radiant energy released per time unit by the burned vegetation during the combustion process (Roberts et al., 2005). FRP data are obtained at the shortwave infrared wavelength, around $4 \mu \mathrm{m}$ (Wooster et al., 2005). The biomass consumption coefficient can be estimated by the linear relationship that exists between FRP and the vegetation consumption rate (Wooster et al., 2005; Freeborn et al., 2008; Pereira et al., 2012). The burned biomass amount can be estimated using Eq. (2) (Wooster et al. (2005), where $B C R$ is the biomass consumption rate $\left(\mathrm{kg} \mathrm{s}^{-1}\right) ; C_{e}$ is the biomass consumption coefficient $\left(\mathrm{kg} \mathrm{MJ}^{-1}\right)$; and $F R P$ is the fire radiative power $\left(\mathrm{MJ} \mathrm{s}^{-1}\right)$, from satellite data.

$$
B C R=C_{e} \times F R P
$$

The biomass consumption coefficient value depends on both the energy released during the combustion process and the amount of vegetation burned during this process (Wooster et al., 2005). The vegetation type is an important variable in the estimation of the biomass consumption coefficient. The environmental factors, such as humidity rate and combustible material supply, can modulate the amount of energy released by the fire and the combustion duration (Wooster et al., 2005; Freeborn et al., 2008; Pereira et al., 2012; and Kaiser et al., 2012).

The FRP algorithm was validated in studies of the Australian savannah (Maier et al., 2013) and the Brazilian Amazon (Schroeder et al., 2008). The FRP values provide information about fire dynamics and emissions, particularly in areas where the wildfires are frequent such as on the African continent (Roberts et al., 2009) and in northern Australia (Boschetti and Roy, 2009); FRP values can also characterize global fire occurrence (Hantson et al., 2013). However, despite validation in the field, the simultaneous use of remote sensing data and parameters derived from field experiments must be cautious, considering the influence of the atmosphere over the satellite image values (Schroeder et al., 2014).

The aim of this study is to estimate the rate of biomass consumption and the biomass consumption coefficient for the southern Brazilian grasslands in the Atlantic Forest biome, using both satellite data and field data.

\section{Material and Methods}

The study area is the South Brazilian Plateau, located in the municipality of André da Rocha, Rio Grande do Sul, Brazil (Fig. 1). Situated at an altitude of $800 \mathrm{~m}$ within the Atlantic Forrest biome, the study area comprises a transitional zone between grasslands and forests. According to Köppen's classification, the climate is humid temperate $(\mathrm{Cfb})$; the annual average precipitation is $1800 \mathrm{~mm}$ and the annual average temperature is $16^{\circ} \mathrm{C}$. This study area was chosen based on legacy field experiments that allowed the quantification of aboveground biomass density, which is a characteristic of each vegetation type and was used to estimate the burned biomass amount.

The biomass consumption by fire was calculated using Eq.(1) and parameters obtained from field experiments carried out by Fidelis et al. (2010) and by Heringer and Jacques (2002). Based on the field experiment carried out by Heringer and Jacques (2002), the grassland aboveground biomass density in André da Rocha municipality was $0.09 \mathrm{~kg} \mathrm{~m}^{-2}$ in the winter season. This density is related to aboveground biomass and litter amount measured in areas with frequently burnings. Fidelis et al. (2010) conducted an experiment in the municipality of Porto Alegre, RS, Brazil, during the summer season, building a dataset of fire intensity, fire spreading rate, temperature above the soil of burning grassland vegetation, and the combustion efficiency for the southern Brazilian grasslands; the authors found that the fire spreading rate was $0.015 \mathrm{~m} \mathrm{~s}^{-1}$ and the combustion efficiency was $93.8 \%$. 

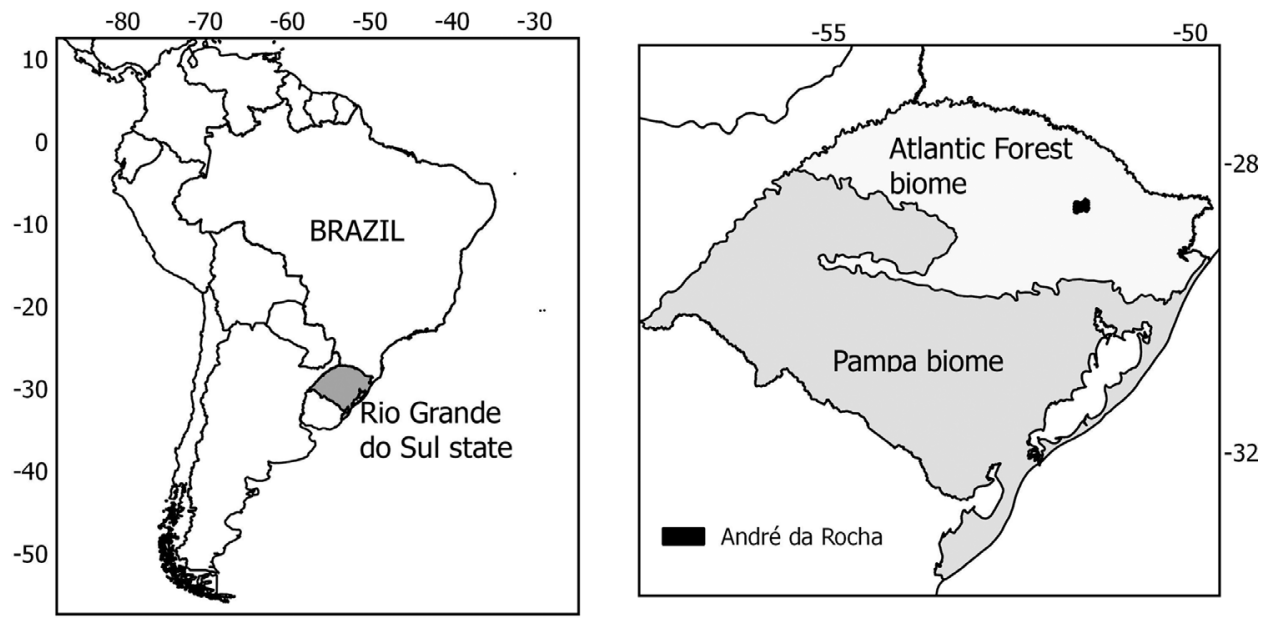

Figure 1 - Study area (André da Rocha Municipality) in the Atlantic Forest biome, Rio Grande do Sul State, Brazil.

Using the INPE Fire Monitoring project database survey (INPE, 2015), we identified three heat points inside our study area, registered by the MODIS sensor on September 4, 2007, at 17:23 UTC. We used the MYD14 product file (MODIS Thermal Anomalies/ Fire 5-MIN L2-SWATH $1 \mathrm{KM}$ V005) for this date to quantify the FRP for these heat points. This product is offered daily as a granule in hierarchical data format (HDF), without geographic projection and with a spatial resolution of $1 \mathrm{~km}$. We performed georeferencing using the Modis Reprojection Tool Swath software, an automatic process using the parameter sets of the MYD03 product [MODIS/Aqua Near Real Time (NRT) Geolocation Fields 5-Min L1A Swath 1 km] with WGS84 datum and coordinates in degree format as the geodetic parameters (Giglio, 2015). The dataset inserted in the HDF file was exported to ASCII format; its contents included the FRP value, mean background brightness temperatures, fire pixel brightness temperature and fire pixel longitude and latitude. Geographic coordinates of each of the three fire pixels identified within the study area, as well as the attribute table for each pixel, were inserted into a Geographic Information System (GIS).

The fire scars were mapped over a Landsat TM image with a spatial resolution of $30 \mathrm{~m}$ and an acquisition date of September 15, 2007, at 13:11 GMT. The georeferenced Landsat image file (with WGS84 geodetic parameters and UTM coordinates) was obtained from USGS Earth Explorer database (USGS, 2015) and inserted into the GIS to identify the fire scars borders and to quantify the total burned area surrounding the MODIS fire pixels coordinates. re created three circular buffers with a $500 \mathrm{~m}$ radius around the coordinates of each fire pixel. Each buffer diameter was equivalent in length to one side of a MYD14 product pixel $(1 \mathrm{~km})$. Were mapped the fire scars that fell within the buffers' area, using visual interpretation of a color composite image consisting of the red, near infrared and shortwave infrared TM bands. The burned areas calculated inside each buffer are collectively referred to as the monitored areas and individually identified as Area 1, Area 2 and Area 3.

To estimate the biomass consumption coefficient $\left(C_{e}\right)$ in Eq.(2), the average Fire Radiative Power (FRP) was obtained from the mean value of the three MODIS fire pixels. The average biomass consumption rate (BCR) was based on the total biomass consumption (BC) value, which is the summed values of the three monitored areas. To convert total biomass consumption into biomass consumption rate, the following assumptions were made: the fire frontline spread equally in all directions across the burning plain (circular spreading), and the fire spreading rate was $0.015 \mathrm{~m} \mathrm{~s}^{-1}$ (Fidelis et al., 2010). The result was the total burning time inside the buffers. To estimate the average biomass consumption rate $\left(\mathrm{kg} \mathrm{s}^{-1}\right)$, the total biomass consumption $(\mathrm{kg})$ and the duration of the burn (seconds) were used. The biomass consumption coefficient $\left(\mathrm{kg} \mathrm{MJ}^{-1}\right)$ was calculated using the average BCR and average FRP.

\section{Results and Discussion}

The fire locations were determined from the three heat points identified by the MYD14 product coordinates (28.639s, $51.558 \mathrm{w} ; 28.637 \mathrm{~s}, 51.547 \mathrm{w} ; 28.667 \mathrm{~s}, 51.567 \mathrm{w})$ (Fig. 2). Figure 2A displays the grassland area with the fire scar, as identified on the Landsat image. The three fire scars shapes indicate that the heat points were part of the same burning, as these points are on the same fire scar border. Figure 2B displays the grassland areas with fire scars inside the $500-\mathrm{m}$ radius buffer around the central point of the heat pixel. These fire scars within the buffer areas validated the fire occurrence identified initially by the MYD14 product.

Table 1 presents the fire scars areas $\left(\mathrm{m}^{2}\right)$; the biomass consumption (BC) by fire, calculated using Eq. (1), with the grassland aboveground biomass density of $0.09 \mathrm{~kg} \mathrm{~m}^{-2}$ (Heringer and Jacques, 2002), and the FRP values for each monitored area (obtained from the MYD14 product) as 


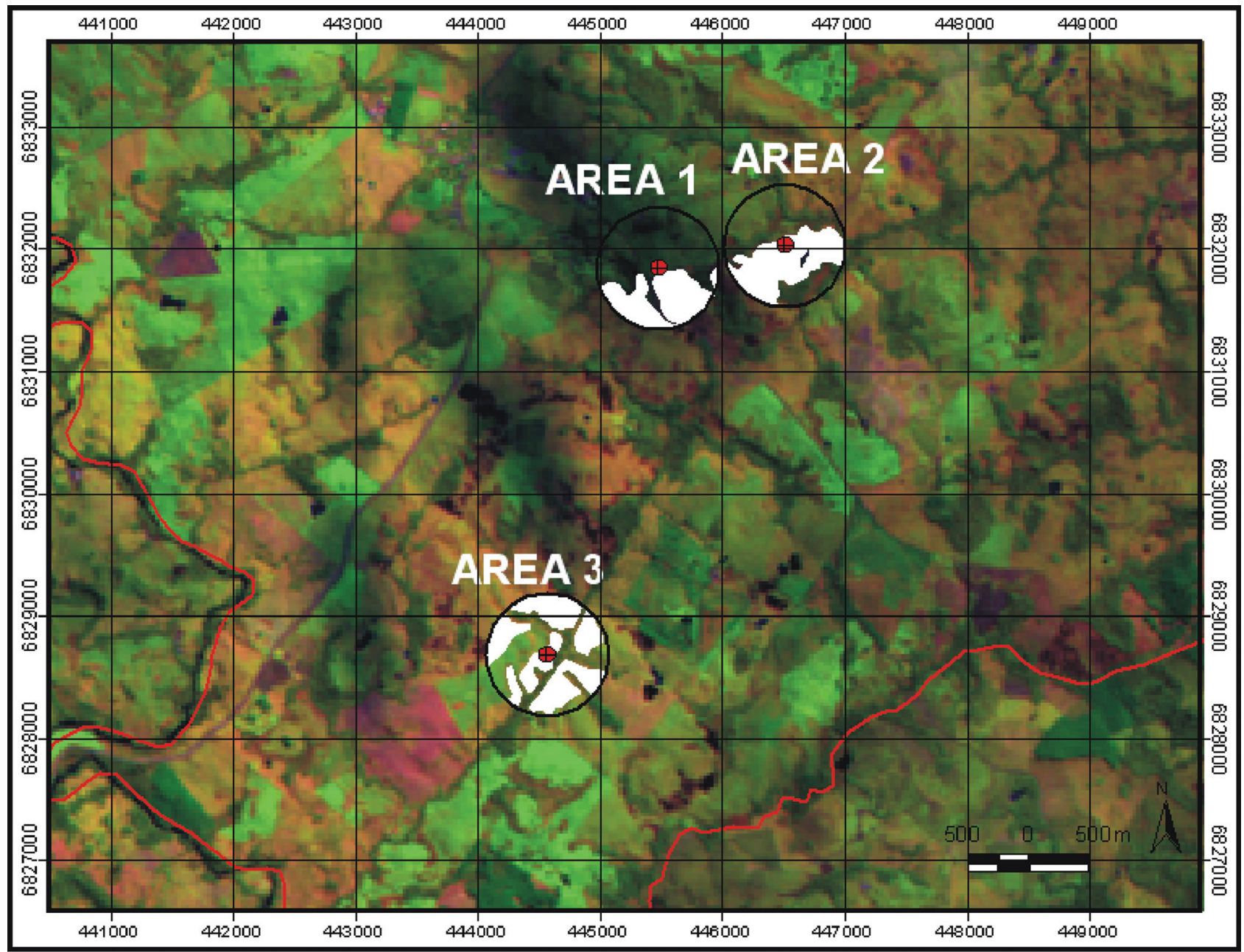

Coord in ate system: U TM zone 22, D atum 'ill GS84.

Origin of coordinates: $51^{\circ}$ 'Wu' and Equator, increased by the constants $500,000 \mathrm{~m}$ and $10,000,000 \mathrm{~m}$, respectively.
LEGEND
(Central coordinate of the fire pixel (MYD14)
- Study area limit
Buffer with $500 m$ of radius generate from the central coordinate of the fire pixel
Grassland fire scar

Figure 2 - Location of the fire pixel and the fire scars (A) and fire scar area mapped inside the buffer area (B) over a Landsat image, in André da Rocha, RS, Brazil.

Table 1 - The fire scar areas, the Fire Radiative Power (FRP) values and the biomass consumed (BC) by fire for each burned grasslands area in Andre da Rocha, RS, Brazil.

\begin{tabular}{llll}
\hline & Fire scar $\left(\mathrm{m}^{2}\right)$ & FRP $(\mathrm{MW})$ & $\mathrm{BC}(\mathrm{kg})$ \\
\hline Area 1 & $267,229.13$ & 07.21 & $22,842.00$ \\
Area 2 & $310,402.24$ & 13.80 & $26,226.00$ \\
Area 3 & $412,724.26$ & 06.76 & $34,686.00$ \\
Total & $990,355.63$ & 27.77 & $83,754.00$ \\
\hline
\end{tabular}

well as the sum for each variable. Although Area 2 has an intermediate value for biomass consumption, its FRP value is high; this can be explained by the differences in fire intensity between the fire fronts such as the back-fire and head-fire. The intensity of a head-fire is considerably higher than a back-fire, both in in situ records and in orbital data used to estimate the FRP (Smith and Wooster, 2005). For the present work no field information was found about the fire situation that corresponded temporally with the MODIS sensor image; therefore, we were unable to identify any type of fire front based on the MYD14 product, due 
to the small number of recorded fire foci as well as the lack of plumes in the image.

To estimate the biomass consumption coefficient $\left(\mathrm{kg} \mathrm{MJ}{ }^{-1}\right)$ for the southern Brazilian grasslands, the three burned areas were considered as one single burning. To estimate the biomass consumption rate $\left(\mathrm{kg} \mathrm{s}^{-1}\right)$ for this burning, were calculated the total burning time, using the total fire scar area (Table 1) to calculate a new circumference radius value $(561 \mathrm{~m})$ for the single burning. Using the fire spread rate $\left(0.015 \mathrm{~m} \mathrm{~s}^{-1}\right)$ (Fidelis et al., 2010), the total burning time was estimated to be $37,400 \mathrm{~s}$, or $10 \mathrm{~h}$. Considering the total biomass consumption by fire (Table 1) and the total biomass consumption time estimates, the biomass consumption rate for the southern Brazilian grasslands was estimated to be $2.237 \mathrm{~kg} \mathrm{~s}^{-1}$.

The average FRP of $9.256 \mathrm{MJ} \mathrm{s}^{-1}$, estimated from the three areas' FRP values, was applied to the single burning (Table 1). The average FRP and the biomass consumption rate were used to estimate a biomass consumption coefficient of $0.242 \mathrm{~kg} \mathrm{MJ}^{-1}$ for the southern Brazilian grasslands. Wooster et al. (2005) estimated a biomass consumption coefficient of $0.368 \mathrm{~kg} \mathrm{MJ}^{-1}$ for savanna vegetation. Freeborn et al. (2008) estimated a biomass consumption coefficient of $0.710 \mathrm{~kg} \mathrm{MJ}^{-1}$ from experiments with a mix of arboreal and grassland vegetation found in the US forest preservation areas. Pereira et al. (2012) estimated a biomass consumption coefficient of $0.949 \mathrm{~kg} \mathrm{MJ}^{-1}$ for different grasslands Cerrado typologies in Brazil. The fireline intensity measurements in situ suggest that southern Brazilian grasslands have lower values than other grassland areas such as those in the African, Australian, Venezuelan savannas, American prairies and Cerrado region in Brazil (Fidelis et al., 2010). The low fireline intensity can explain the low biomass consumption coefficient found in this work.

The feasibility of using Landsat satellite images to identify the fire scars was demonstrated by Bastarrika et al. (2011) and also verified in this work. The spatial resolution of the MODIS sensor $(1 \mathrm{~km})$ for the MYD14 products assigns a single record to the entire $1 \mathrm{~km} \times 1 \mathrm{~km}$ area (Peterson and Wang, 2013). Due to this limitation, is not possible to determine the exact location of the fire within the pixel or whether only one or several fire spots existed inside the MODIS pixel (Giglio, Csiszar and Justice, 2006), especially considering the small size of burnings in this region. Despite of this limitation the FRP values can be found over satellite images in this region, allowing the use of FRP technique for the southern Brazilian grasslands.

The southern Brazilian grasslands biomass consumption rate and the biomass consumption coefficient estimates were based on a dataset obtained at different time and spatial scales. Two different field experiments measured the burnings on dates prior to the satellite data acquisition, with one of the burnings in a location different than where the rest of work was used. This dataset integration was necessary to estimate the biomass consumption coefficient without having to conduct an experimental burning at the same moment that the satellite passed by over the study area. However, this approach allows the operational use of satellite information on burnings in the temperate Brazilian grasslands, with a local biomass consumption coefficient.

\section{Conclusions}

For the Brazilian Southern grasslands in Atlantic Forest biome, the biomass consumption rate was estimated to be $2.237 \mathrm{~kg} \mathrm{~s}^{-1}$, and the biomass consumption coefficient was $0.242 \mathrm{~kg} \mathrm{MJ}^{-1}$. The knowledge of this coefficient enables the use of the Fire Radiative Power measured by remotely sensed images to obtain more quantitative information about the temperate grassland burnings in Southern Brazil. Despite the limitations of the remote sensed techniques, the FRP measurements from satellite data can be used to monitor the amount of burned biomass, as these measurements constitute an accurate, validated and daily updated dataset with surveillance of the entire grasslands area.

\section{Acknowledgments}

Thanks to Coordenação de Aperfeiçoamento de Pessoal de Nível Superior (CAPES) for the first author grant support.

\section{References}

ANDREAE, M.O. Biomass burning: Its history, use and distribution and its impact on environmental quality and global climate. In: LEVINE, J. Global biomass burning: Atmospheric, Climatic and Biospheric Implications. Cambridge: MIY Press. pp 3-21. 1991.

ANDREAE, M.O.; MERLET, P. Emission of trace gases and aerosols from biomass burning. Global Biogeochemical Cycles, v. 15, n. 4, p. 955-966, 2001.

BASTARRIKA, A.; CHUVIECO, E.; MARTÍN, M.P. Mapping burned areas from Landsat TM/ETM+ data with a twophase algorithm: Balancing omission and commission errors. Remote Sensing of Environment, v. 115, n. 4, p. 1003-1012, 2011.

BOLDRINI, I.I. A flora dos campos do Rio Grande do Sul. In: Pillar, V. D.; Müller, S. C.; Castilhos, Z. M. de S.; Jacques, A. V. A Campos sulinos: conservação e uso sustentável da biodiversidade. Brasília: MMA, 2009. p. 63-77.

BOSCHETTI, L.; ROY, D.P. Strategies for the fusion of satellite fire radiative power with burned area data for fire radiative energy derivation. Journal of Geophysical Research, v. 114, p.1-10, 2009.

CHRISTIAN, T.J.; YOKELSON, R.J.; CARVALHO JR, J.A.; GRIFFITH, D.W.T.; ALVARADO, E.C.; SANTOS, J.C.; SOARES NETO, T.G.; VERAS, C.A.G.; HAO, W.M. The tropical forest and fire emissions experiment: Trace gases emitted by smoldering logs and dung from deforestation and pasture fires in Brazil. Journal of Geophysical Research, v. 112, DI8308, 2007.

FIDELIS, A.; DELGADO-CARTAY, D.; BLANCO, C.C.; MÜLLER, S.C.; PILLAR, VD.; PFADENHAUER, J. Fire 
intensity and severity in Brazilian campos grasslands. Interciencia-Caracas, v. 35, n. 10, p. 739-745, 2010.

FIDELIS, A.; BLANCO, C. C.; MÜLLER, S.C.; PILLAR V.D.; PFADENHAUER, J. Short-term changes caused by fire and mowing in Brazilian campos grasslands with different long-term fire histories. Journal of Vegetation Science, v. 23, p. 552-562, 2012.

FREITAS, SR.; LONGO, K. M.; SILVA DIAS, M.A.F.; SILVA DIAS, P.L. 2005. Emissões de queimadas em ecossistemas da América do Sul. Estudos Avançados, v. 19, n. 53, p. 167-185, 2005.

FREEBORN, P.H.; WOOSTER, M.J.; HAO, WM.; RYAN, C. A.; NORDGREN, B.L.; BAKER, S.P.; ICHOKU, C. Relationships between energy release, fuel mass loss, and trace gas and aerosol emissions during laboratory biomass fires. Journal of Geophysical Research, v. 113, D01301, p. 1-17, 2008.

GIGLIO, L. MODIS Collection 6 Active Fire Product User's Guide, available in https://earthdata.nasa.gov/files/MODIS_C6_Fire_User_Gu ide_A.pdf, accessed on April, 30, 2015.

GIGLIO, L; CSISZAR, I; JUSTICE, C.O. Global distribution and seasonality of active fires as observed with the Terra and Aqua Moderate Resolution Imaging Spectroradiometer (MODIS) sensors. Journal of Geophysical Research, v. 111, GO2016, 2006.

HANTSON, S. PADILLA, D.C.; CHUVIECO, E. Strengths and weaknesses of MODIS hotspots to characterize global fire occurrence. Remote Sensing of Environment, v. 131, p. 152-159, 2013.

HERINGER, I.; JACQUES, A.V.A. Forage production and litter in native pasture under distinct alternative management practices in relation to burning. [In Portuguese]. Revista Brasileira de Zootecnia, v. 31, n. 2, p. 599-604, 2002.

INPE (Instituto Nacional de Pesquisas Espaciais) Portal de Monitoramento de queimadas e incêndios: SIG queimadas. Available http://pirandira.cptec.inpe.br/queimadas/qmagoogle.html. Accessed on March 6, 2015.

KAISER, J.W.; HEIL, A.; ANDREAE, M.O.; BENEDETTI, A.; CHUBAROVA, N.; JONES, L.; MORCRETTE, J-J.; RAZINGER, M.; SCHULTZ, M.G.; SUTTIE, M.; VAN DER WERF, G.R. Biomass burning emissions estimated with a global fire assimilation system based on observed fire radiative power. Biogeosciences, v. 9, n. 1, p.527-554, 2012.

LONGO, K.M.; FREITAS, S.R.; ANDREAE, M.O.; YOKELSON, R.; ARTAXO, P. Biomass burning in Amazonia: Emissions, long-range transport of smoke and its regional and remote impacts. In: KELLER, M.; BUSTAMANTE, M.; DIAS, P.S. Amazonia and global change. Washington DC: American Geophysical Union, p. 207-232. 2009.

MAIER, S.W.; RUSSELL-SMITH, J.; EDWARDS,A.C.; YATES, C. Sensitivity of the MODIS fire detection algorithm (MOD14) in the savanna region of the Northern Territory, Australia. ISPRS Journal of Photogrammetry and Remote Sensing, v. 76, p. 11-16, 2013.
OVERBECK, G.E.; MÜLLER, S.C.; FIDELIS, A.; PFADENHAUER, J.; PILLAR, V.D; BLANCO, C.C.; BOLDRINI, I.I.; BOTH, R.; FORNECK, E.D. Brazil's neglected biome: the southern Brazilian campos. Perspectives in Plant Ecology, Evolutions and Systematics, v. 9, n. 2, p. 101-116, 2007.

PEREIRA, G; CARDOZO, F.S.; SILVA, F.B.; MORAES, E.C.; FERREIRA, N.J.; FREITAS, S.R.; SHIMABUKURO, Y.E.; BREUNIG, F.M.; VIANA, D.R. Determination and modeling the consumption rate of burned biomass. [In Portuguese]. Revista Brasileira de Meteorologia, v. 27, n. 1, p. 13-22, 2012.

PETERSON, D.; WANG J. A sub-pixel-based calculation of fire radiative power from MODIS observations: 2. Sensitivity analysis and potential fire weather application Remote Sensing of Environment, v. 129, p. 231-249, 2013.

ROBERTS, G.; WOOSTER, M.J.; PERRY, G.L.W.; DRAKE, N. Retrievel of biomass combustion rates and totals from fire radiative power observations: Application to southnern Africa using geostationary SEVIRI imagery. Journal of Geophysical Research, v. 110, D21111, 2005.

ROBERTS, G.; WOOSTER, M.J.; LAGOUDAKIS, E. Annual and diurnal African biomass burning temporal dynamics. Biogeosciences, v. 6 p. 849-866, 2009.

SCHROEDER, W. ; PRINS,E.; GIGLIO,L.; CSISZAR, I.; SCHMIDT, C.; MORISETTE, J.T.; MORTON, D. Validation of GOES and MODIS active fire detection products using ASTER and ETM+ data. Remote Sensing of Environment, v. 112, p. 2711-2726, 2008.

SCHROEDER, W.; ELLICOTT, E.; ICHOKU, C.; ELLISON, L.; DICKINSON, M.B.; OTTMAR, R.D.; CLEMENTS, C.; HALL, D.; AMBROSIA, V.; KREMENS, R. Integrated active fire retrievals and biomass burning emissions using complementary near-coincident ground, airborne and spaceborne sensor data. Remote Sensing of Environment, v. 140, p. 719-730, 2014.

SEILER, W.; CRUTZEN, PJ. Estimates of gross and net fluxes of carbon between the biosphere and the atmosphere from biomass burning. Climate Change, v. 2, n.3, p. 207-247, 1980. doi: 10.1007/BF00137988.

SMITH, A.M; WOOSTER, M.J. Remote classification of head and backfire types from MODIS fire radiative power and smoke plume observations. International Journal of Wildland Fire, v.14, p.249-254, 2005. doi:10.1071/WF05012

USGS (U.S. Geological Survey) Earth Explorer database, available at: http://earthexplorer.usgs.gov. Accessed on May 12, 2015.

WHELAN, R.J. The ecology of fire. UK: Cambridge University Press, 360 p. 1995.

WOOSTER, M.J.; ROBERTS, G.; PERRY, W. Retrieval of biomass combustion rates and totals from fire radiative power observations: FRP derivation and calibration relationships between biomass consumption and fire radiative energy release. Journal of Geophysical Research, v. 110, D24311, 2005.

This is an Open Access article distributed under the terms of the Creative Commons Attribution Non-Commercial License which permits unrestricted non-commercial use, distribution, and reproduction in any medium provided the original work is properly cited. 